Mahathir's place in history is a contested issue and a difficult one to judge largely because he is still making history. Meanwhile, the long awaited book A Doctor in the House: the Memoirs of Tun Dr Mahathir Mohamad has just come out. Those interested in the issue of Mahathir's legacy and his place in history are well advised to read this memoir. Wain's book would be of great help to readers who seek a critical evaluation of the memoir.

\title{
Seyyed Hossein Nasr (in conversation with Muzaffar Iqbal), Islam, Science, Muslims, and Technology
}

(Kuala Lumpur: Islamic Book Trust, and Sherwood Park: Al-Qalam Publishing, 2010, repr.), xii+212 pp. ISBN: 978-0-9738744-2-6 (paperback). US\$19.85

Norhayati Mustapha International Institute of Advanced Islamic Studies (IAIS) Malaysia

At the outset Muzaffar Iqbal explains the context within which the book was conceived by relating his first encounter with Professor Seyyed Hossein Nasr in Islamabad, March 1995, where the latter was due to deliver a keynote address at an international conference organised by the OIC Standing Committee on Scientific and Technological Cooperation (COMSTECH) on "Science in Islamic Polity in the Twenty-First Century". Nasr follows with his essay on "The Cosmos as Subject of Scientific Study", after which four separate conversations occupy the second section while the third and last sections present the text of Nasr's keynote address at the said conference.

In the conversation on "Islam, Science and Muslims", Nasr emphasises the need to create an authentic Islamic philosophy and science of nature on the basis of both our own scientific tradition and discoveries of the Western world. He mentions Islamic institutions which offer modern sciences and other subjects taught in modern Western institutions but in the matrix of Islamic thought, one of which he set up himself, i.e. the former Imperial Iranian Academy of Philosophy. Throughout he laments the error of modern science in forgetting the spiritual dimension in nature, likening it to "cutting off the Hands of God from His creation", and puts forth the idea of creating islands within the Muslim world for the continuation and practice of alternative technologies from the Islamic viewpoint to include the fields of medicine, pharmacology and agriculture.

Conversing on "Islam, Muslims, and Modern Technology", Nasr defines the word 'technology' from its origins in Greek (téchnē, meaning 'an art'), Latin (ars, also meaning 'an art'), Persian (șan 'at which refers to both 'technology' and 'art') and Arabic (sina 'ah, with the same meaning), inferring that linguistically and 
conceptually no division occurs between technology and art while in the West the two are separate. Traditional technologies, he notes, were extensions of our hands, senses, and other parts of our bodies, exemplified by the traditional craftsmen of Isfahan who produce geometric patterns in stucco, stone or wood; and traditional hand-weavers of the Persian carpet. Modern technology on the other hand transfers human knowledge to the machine, resulting in people forgetting how to spell or calculate because the computer 'does everything'. The process of mass production no longer involves creativity and has become boring and tedious. Modern technology has removed the love and devotion to the creation of an object and the spiritual content of work. While not denying the necessity for telephones and electricity, he believes that much can be preserved by the Islamic world: in agriculture, for example, he suggests having small farms rather than adopting large agro-businesses which use genetically engineered seeds.

Nasr is all for a 'saner' way of life, adamant that we must not be like a "[...] sleepwalker, accepting anything that comes along without thinking of the consequences". Taking the cellphone as a case in point, he decries the vision of pilgrims circumambulating the Ka 'bah with their cellphones ringing. He sees a glimmer of hope, however, in Islamic architecture and design deeply rooted in traditional technologies. Besides preserving what has not been destroyed in cities such as Fez in Morocco, Yazd in Iran, parts of Damascus around the Umayyad mosque, and the old quarters in Cairo, young architects can be inspired by traditional Islamic urban design, architectural technology and forms in the design of new homes, towns and villages.

The conversation "On the Environmental Crisis" points to modern technology and its applications being driven by greed and the creation of artificial needs all over the globe. The consequent disruption in balance and harmony leads to extinction of species and destruction of their natural habitat. Nasr links pollution to the food chain, relating it also to the rising incidence of cancers. Origins of the environmental crisis are traced to the Industrial Revolution largely in the Western world from the nineteenth century onwards, and the anthropogenic humanism of the Renaissance era which makes man the centre of this new system of thought, not God. He advocates alternate technologies which reduce the environmental impact of our activities, touching upon the use of building materials, e.g. locally-produced and environmentfriendly mud, bricks and stone, instead of metal, to create remarkable architecture.

The dearth of environmental discourse among the 'ulama ' is also highlighted and Nasr recommends a changing of mindsets of the Muslim world at two levels: (i) the learned who are the 'opinion-makers', and (ii) small action groups committed to their immediate environment by organic farming, tree planting, etc. He notes the opposition to the environmental movement which exists in any religion-Christians who believe that Christ will soon return to Earth and that God will rejuvenate His 
creation; and Muslims who await the coming of the Mahdī, when oppression and injustice will be overcome, neglecting to look at nature. The Qur'ān and Hadìth, however, teach us that as vicegerents on earth, our duty toward the world of nature does not change whether we are living in the eleventh or first hour.

In "Biological Origins" Nasr challenges the generally accepted Darwinian and neo-Darwinian theories and offers alternate explanations based on the qur'ānic worldview. Lastly, his keynote address "The Islamic Worldview and Modern Science" proposes the following steps: (i) to stop the worship-like attitude toward modern science and technology; (ii) to conduct an in-depth study of traditional Islamic sources from the Qur'ān and Hadith to all the traditional works on modern science, philosophy, theology, cosmology, etc.; (iii) to study modern science at the highest level, in particular the basic sciences or what the West calls pure science; (iv) to revive the traditional Islamic sciences whenever and wherever possible, especially in medicine, pharmacology, agriculture, and architecture; and (v) re-wed science and ethics through the very theoretical structure and philosophical foundation of science. A 'word about technology' at the end reiterates that it was technology rather than science that enabled the West to dominate the rest of the globe.

In concluding, Nasr stresses that any science which could legitimately be called 'Islamic science' and not be disruptive of the whole Islamic order must be aware of the Vertical Cause of all things, along with the horizontal, a science that issues from and returns to the Real (al-Haqq), Who is the Cause of all things.

Islam, Science, Muslims, and Technology is a compendium of Nasr's thoughts through the early years of the first decade in the new millennium, the conversations having taken place from 2003 to 2007. As hinted by Muzaffar Iqbal, interest in writing the book was possibly sparked much earlier on, spurred by the 'less than enthusiastic' response from Pakistan's then prevailing political regime in 1995 to Nasr's keynote address in Islamabad.

In sum, coming from the mind of one of the world's most esteemed Islamic thinkers, this readable paperback is a priceless source of wisdom for anyone concerned about the future of Islamic civilisation, particularly the younger generation of scientists and technocrats in the Muslim world. 